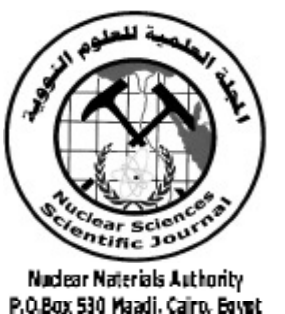

ISSN 2314-5609

Nuclear Sciences Scientific Journal

$5,109-120$

2016

http://www.ssnma.com

\title{
COMPARATIVE STUDY ON THE GEOLOGICAL AND GEOCHEMICAL CHARACTERISTICS OF SOME RARE-METAL GRANITES, SOUTHEASTERN DESERT, EGYPT
}

\author{
MOHAMED M. EL GALY; FARRAGE M. KHALEAL and ANTAR F. BAKHIT \\ Nuclear Materials Authority, P.O. 530, El-Maadi, Cairo, Egypt
}

\begin{abstract}
The Egyptian younger granites are characterized by the presence of more than 14 exposures of raremetal granites. The studied granites are included into three geological modes of occurrence. The first includes Igla and Abu Dabbab plutons, which occur as small stocks of circular, ovoid, or apophyses and leucocratic outcrops. The second comprises the plugs and dyke-like bodies intruded peralkaline granites of Bir Um Hibal. The third includes Homrit Waggat and Muweilha plutons. They cover small areas and exhibit obvious pervasive post magmatic alterations.

The petrographic and mineralogical studies are confirmed by the geochemical investigations indicating that the concerned rare-metal granites being broadly distinguished into magmatic and metasomatic associations. The magmatic granite associations are further subdivided into two subgroups; i) peraluminous granites (Li-mica rich) including Igla and Abu Dabbab plutons and ii) peralkaline granites including Um Hibal pluton. The studied peraluminous granites are generally enriched in $\mathrm{Nb}, \mathrm{Rb}, \mathrm{Ta}, \mathrm{Li}, \mathrm{F}, \mathrm{Y}, \mathrm{Zr}, \mathrm{U}$ and Th elements. The peralkaline granites are enriched in $\mathrm{K}_{2} \mathrm{O}$ oxide as well as $\mathrm{Zr}, \mathrm{Nb}, \mathrm{F}$, $\mathrm{U}$, Th and Ta elements. On the other hand, the metasomatic granite associations are represented by Homrit Waggat and Muweilha plutons. They are characterized by high contents of $\mathrm{Na}_{2} \mathrm{O}$ oxide as well as $\mathrm{Nb}, \mathrm{Ta}, \mathrm{U}$, Th and $\mathrm{Rb}$ elements.

Igla pluton has highest average U \& Th contents (42 ppm \& 58 ppm respectively), while Um Hibal pluton has lowest average $U \&$ Th contents (14 ppm \& 26 ppm respectively)

\section{INTRODUCTION}

The rare metal granites are generally defined as those bearing mineralizations or high concentrations of one or more of $\mathrm{Nb}$, Ta, Zr, Hf, Li, Be, U, Th, W, Sn, Rb, Fe, Cs and REE (Kovalenko, 1978 and Tischendorf, 1977). Such granites are petrologically and geochemically specialized due to their unique and often extreme chemical features. They may be related either to magmatic or post magmatic, metasomatic processes (Ramsy, 1986; Schwartz, 1992; Abdalla and Mohamed, 1999).

They constitute worldwide distributed provinces in several countries (e.g. France; South America; Nigeria, South China; Arabian-Nubien shield). Ramsy (1986) concluded that the specialized felsic plutonic rocks, including granite of the Arabian Nubian Shield are end-products of magmatic differentiation and have mainly magmatic composition except for high contents of incompatible trace elements. On the other hand, Guinsbourg (1972) classified the specialized granites into: i) muscovite granites with rare metals, ii) Limica granites with rare elements and iii) riebeckite-arfvedsonite-aegirine granites with
\end{abstract}


rare-earth elements (REE). Pollard (1995) mentioned that the rare metal granites are broadly divided into peraluminous and peralkaline varieties. The peraluminous variety is enriched in $\mathrm{U}, \mathrm{Ta}, \mathrm{Rb}$ and $\mathrm{Sn}$ mineralizations, while the peralkaline type is more enriched in $\mathrm{Nb}, \mathrm{Zr}$ and LREE mineralzations. This suggests that there is no definite classification of such important granitic rocks. In general the rare metal granites are part of the anorogenic group of granites (A-type); identified by Loiselle and Wones (1979) and Collins et al (1982).

In Egypt, more than 14 rare metal granitic plutons are discovered. These plutons constitute parts of the western span of the Arabian Nubian Shield of the Eastern Desert and represent, in turn, the northern extension of the Mozambiqe belt. They belong genetically to the younger granitic rocks emplaced within a time span from 620-530 Ma (Hassan and Hashad, 1990). Moreover, they comprise the highly evolved phase of the most fractionated variety (G1) of the Egyptian Younger Granites reported by Greenberg (1981). Recently, several occurrences of the rare metal granites of the Eastern Desert were targets of study by many authors (e.g Mohamed et al, 1999). These studies classified the rare metal granites into magmatically and metasomatically groups. Among the fourteen rare metal granitic occurrences presented in the Eastern Desert, the plutons of Igla, Abu Dabbab, Humrit waggat, Muweilha and Um Hibal are chosen for the comparative studies of the geological and geochemical characteristics of these plutons.

The present study aims to compare the geological and geochemical characteristics of Igla, Abu Dabbab, Humrit Waggat, Muweilha and Bir Um Hibal rare metal granites.

\section{METHODOLOGY}

The Thin sections and the polished slabs were prepared in the laboratories of Cairo University. The representative samples of all granitic plutons (55 samples) except those for Muweilha pluton were analyzed for major oxides and trace elements at the laboratories of Nuclear Materials Authority. The three samples of Muweilha pluton were analyzed at the Technical Universtat, Germany.

\section{GEOLOGICAL AND PETROGRAPHI- CAL CHARACTERISTICS}

The field observations showed that the studied rare metal granitic plutons are included into three main geological modes of occurrence:

\section{The First Mode}

The first mode includes Igla and Abu Dabbab rare metal granites. They occur as small stocks of circular, ovoid or apophyses outcrops. They are leucocratic (white to buff in colour) with sharp contacts against their surrounding metavolcano-sedimentary rocks (Fig 1). The concerned granites are commonly formed in zones of transitional faulting associated with tension established following anorogenic compressional event (Pitcher, 1983). They are generally of fine- grained to porphyritic texture and represented by two sub-varieties, albite-rich variety with white colour and K-feldspar-rich variety with buff colour.

\section{The Second Mode}

The second mode is represented by the plugs and dyke-like bodies intruded the ring complexes. It is mainly granites of Bir Um Hibal (Fig. 2). These granites are located on the junction between the ENE transform faults and the NNW deep-seated tectonic zones (Garson and Krs 1976). They are medium-grained, pink in colour and of PermoTriassic age, $223 \pm 9$ Ma (Hashad and El Reedy, 1979).

\section{The Third Mode}

The third mode of rare metal occurrence is represented by two plutons; Humrit waggat and Muweilha plutons. Both plutons 


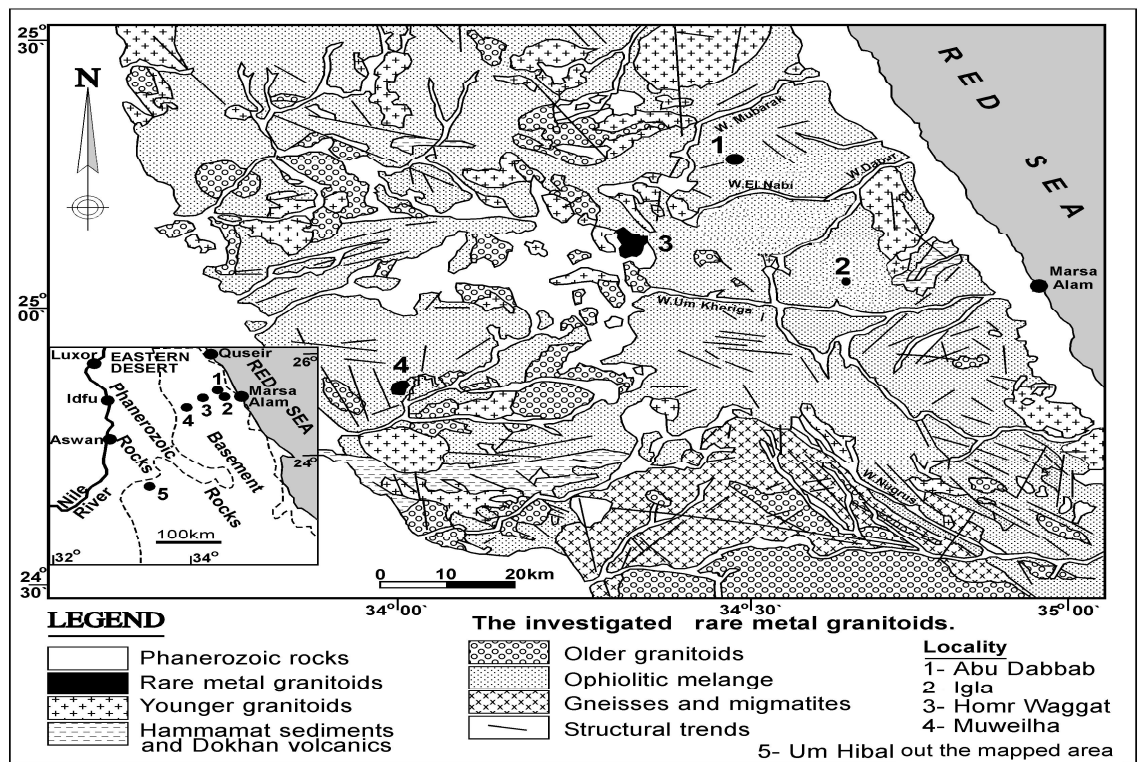

Fig. 1: Regional geological map showing the locations of the investigated rare metal granitoids, Eastern Desert, Egypt (Modified from the geological map of Egypt, 1978)

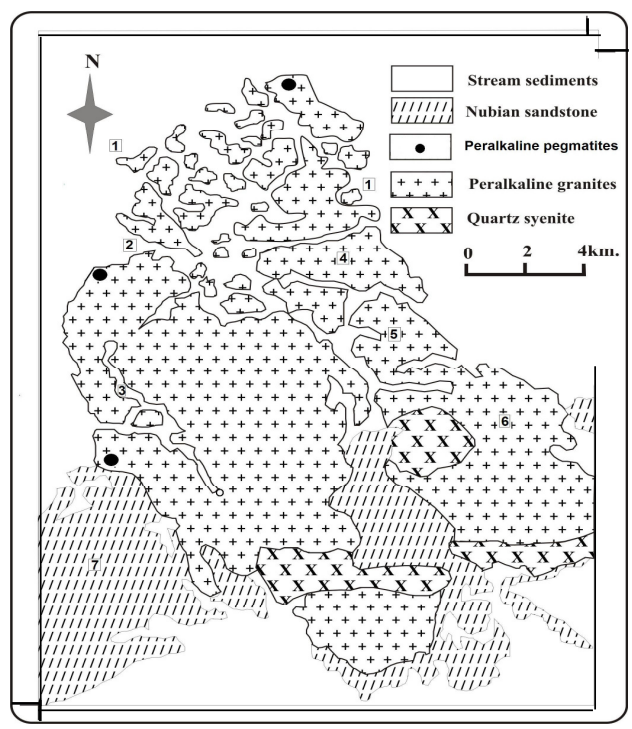

Fig. 2: Geological map of Um Hibal area, Southeastern Desert, Egypt. (After Abdalla and El Afandy, 2003). 1= W. El Arab. 2=W. El Shoum. $3=$ W. Um Hibal. $4=$ G. Um Zagnon. $5=$ G. Dihmit. $6=\mathrm{G}$. Agib. $7=$ G. Um Swan. cover small areas (each measures $1-5 \mathrm{Km}^{2}$ ) and reveal obvious pervasive post magmatic alterations. Humrit waggat granitic pluton is dominated by potassic alteration while $\mathrm{Mu}$ weilha granitic pluton is dominated by sodic alteration.

Based on the petrographical and mineralogical studies carried out on the investigated rare metal granites as well as the classification and nomenclature of similar granites reported by different authors, the current granites are broadly divided into two major granite associations; magmatic and metasomatic associations.

The magmatic granite association is represented by Lithium mica granites, (peraluminous) and peralkaline granites.

\section{The Li-mica granites (Abu Dabbab and Igla plutons)}

These granites consist essentrially of quartz, albite, K-feldspars and Li-mica. To- 
paz, columbite-tantalite, beryl, cassiterite and fluorite are the main accessories. Texturally, they are characterized by fine-grained to porphyritic texture with quartz and K-feldspar phenocrysts embedded in albite-rich groundmass. Zonation is evidenced in typical examples of similar granitic type (e.g. Nuweibi granite, Helba et al, 1997). The lower zone is characterized by zinnwaldite mica, amozonite, albite and dominant hypidiomorphic texture. However, the lower zinnwaldite amazonite albite granite zone is not exposed in the lgla and Abu Dabbab stocks. The upper zone is characterized by white mica, albite and dominant porphyritic texture.

The quartz phynocrysts commonly exhibit snowball-like texture with albite laths arranged concentrically along their growth zones (Fig 3). This texture is suggested to be of primary magmatic origin (e.g. Schwartz, 1992, Helba et al. 1997). The white mica of the upper zone is characterized by high contents of $\mathrm{Si}, \mathrm{Al}, \mathrm{Fe}, \mathrm{Ga}$, Ta, and $\mathrm{Sn}$ and ranges in composition from phengite to muscovite. Columbite-tantalite occurs as bladded, euhedral to subhedral, fine-grained crystals $(0.05-$ $0.25 \mathrm{~mm}$ in size) included in micas and dispersed among the groundmass constituents.

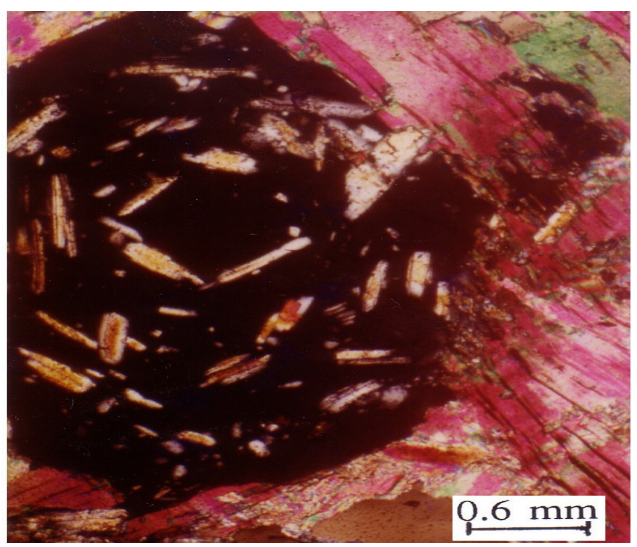

Fig. 3: Photomicrograph showing typical snow-balled quartz phenocrysts embedded in fine grained albite-rich groundmass and $\mathrm{Li}$ muscovite, XPL
They commonly exhibit zoning, with $\mathrm{Nb}$ rich cores and Ta-rich rims, and are ranged in composition from mangano-columbite to mangano-tantalite.

\section{The peralkaline granites (Bir Um Hibal pluton)}

These are composed mainly of quartz, perthite, albite and alkali amphiboles and pyroxenes (riebeckite and arvfedsonite). They are hypersolvus, medium-grained with equigranular to porphyritic texture. Despite the prevalence of primary textures, secondary albite and patch perthites are observed reflecting late-magmatic deuteric alterations.

\section{The metasomatic granite association (apogranites)}

This is generally characterized by vertical petrographical zoning with a lower unaltered zone followed upward by microclinization, albitization and greisenization zones (Pollard, 1989). In the studied apogranites, the complete sequence of the metasomatic zonation is not so perfect. The lower unaltered zone is either represented by biotite granite (Humrit Waggat) or alkali feldspar granite (Muweilha). Microclinzation and albitization zones are well developed at Humrit Waggat and are recorded at other locations (Um Ara and Abu Rusheid, Mohamed, 1989; Abdalla et al., 1994), whereas albitization and greisenization zones are principally developed at Muweilha and are recorded at Homrit Akarem (Abdalla and Mohamed, 1999). Humrit waggat metasomatized granites represent three zones: unaltered lower zone of biotite granite, potassium feldsparization (microclinization) zone and less developed albitization zones. On the other hand, Muweilha metasomatized granite is represented by lower albitization zone followed by upper greisenization zone (Figs. 4-10).

The lower unaltered alkali-feldspar granite zone is characterized by well developed miarolitic vugs $(3-10 \mathrm{~cm}$ in diameter) filled with fragmented quartz in a felsitic matrix, 


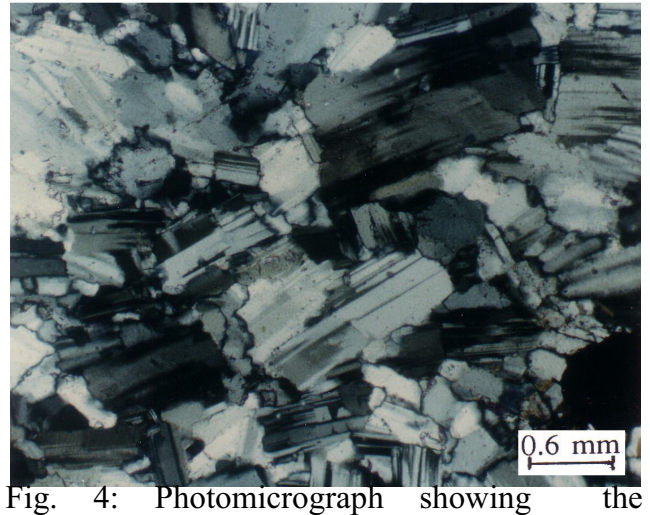
development of subsolidus albite clusters which attack the preexisting quartz, XPL

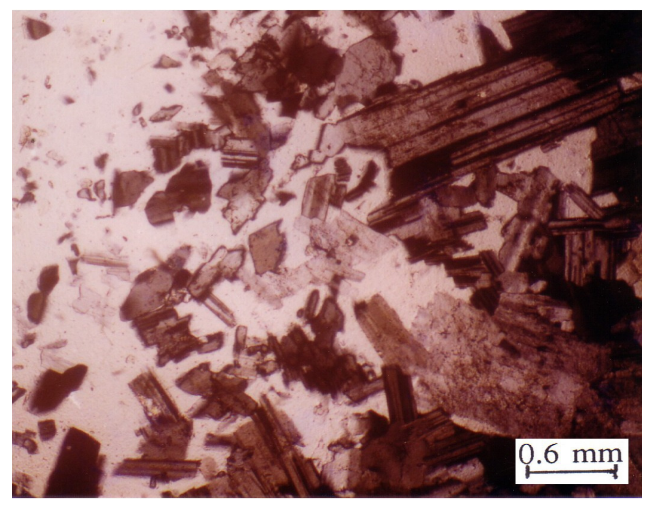

Fig. 5: Photomicrograph showing the albitite rock is formed when the Na-metasomatism becomes overwhelming, XPL

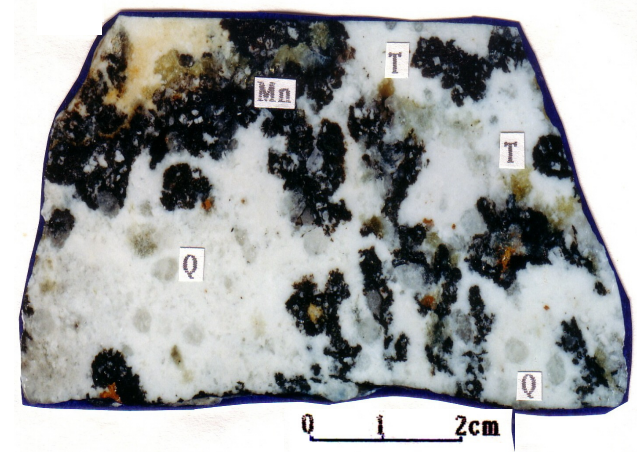

Fig. 6: Polished rock slabs showing snow balled porphyritic quartz (Q) and topaz (T) in fine-grained albite-rich matrix. Mn-oxide impregnation $(\mathrm{Mn})$ is also observed

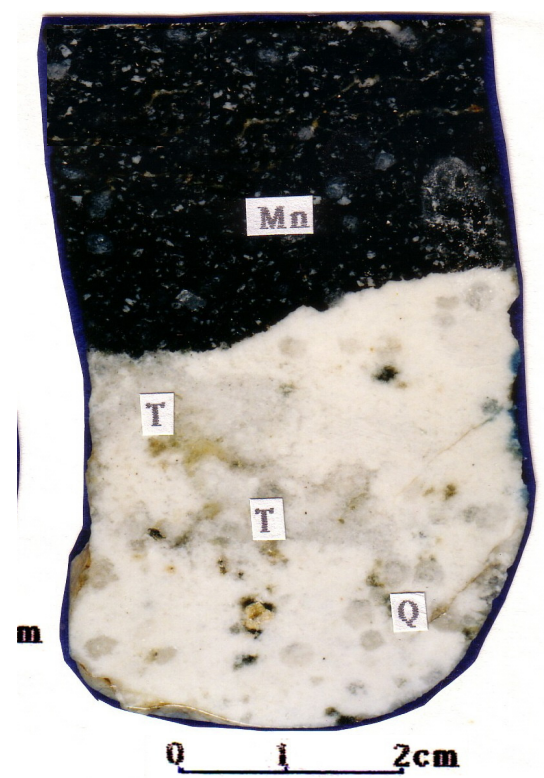

Fig. 7: Polished rock slabs showing an overwheiming Mn-oxide alteration front attacking the albite granite $(\mathrm{T})$

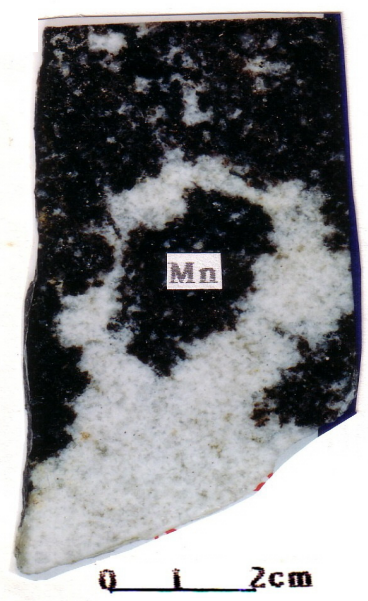

Fig. 8: Polished rock slabs showing fine grained albite granite from the Li-albite granite at Abu Dabbab 


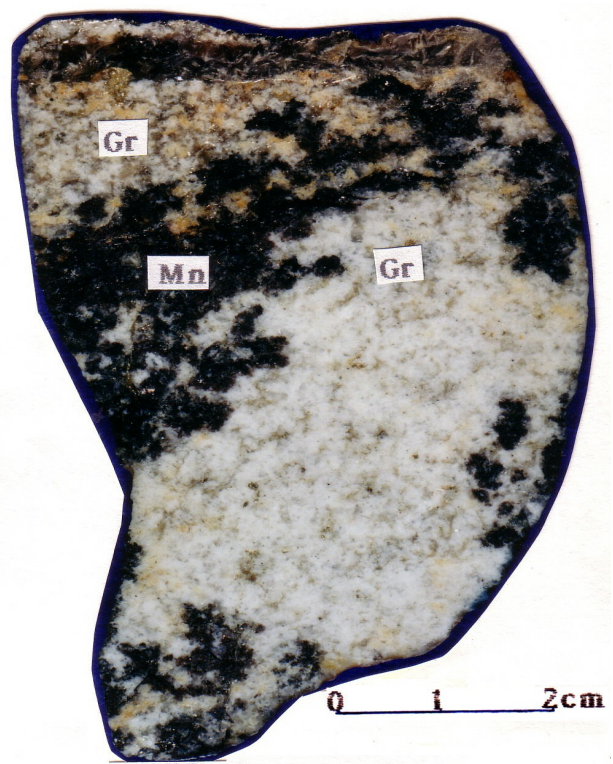

Fig. 9: Polished rock slabs showing Greisenized (Gr) albite granite. Notice that the black zinnwaldite on Fig.6, is replaced by greenish muscovite on Fig. 8

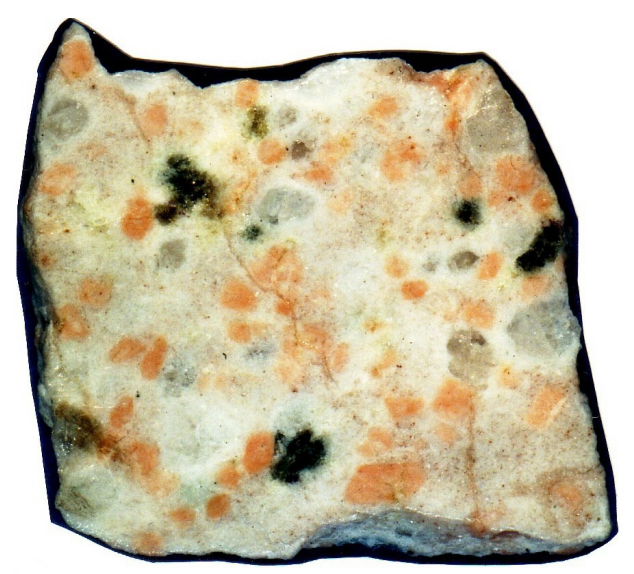

Fig. 10: Polished rock slabs showing the albitized granite from the Muweilha apogranites. Notice the relics of k-feldspar crystals set in albite-rich groundmass. and degassing breccias in the form of fragmented granites cemented by quartz and fluorite. The mineral constituents of this zone are microcline, perthite, albite (An2-3), graphic quartz and minor white mica.

\section{GEOCHEMICAL CHARACTERISTICS}

A total of 58 samples representing the studied rare metal granites were chemically analyzed for the major oxides as well as some trace elements. The obtained data are listed in Table (1). The rare metal granites of Egypt are genetically related to the younger granites, especially the most evolved third phase of Sabet et al. (1976) which matches group I of Greenberg (1981) and $\mathrm{G}_{\alpha}$ category of ElGaby et al. (1990). The composition of that phase recorded in association with Homrit Waggat rare metal granite is used as a normalized one for the study rock varieties. The composition of low Ca-granite of Turekian and Wedepohl (1961) and the composition of specialized granite of Tischendorf (1977) are also plotted for comparison.

The studied rare metal granites are characterized by higher contents of $\mathrm{Na}_{2} \mathrm{O}, \mathrm{Nb}, \mathrm{Ga}$, and $\mathrm{Zn}$ and lower contents of $\mathrm{CaO}, \mathrm{Sr}$, and $\mathrm{Ba}$ than the precursor biotite granite (Table 1). They have higher contents of $\mathrm{Na}_{2} \mathrm{O}$ and / or $\mathrm{K}_{2} \mathrm{O}, \mathrm{Rb}, \mathrm{Zr}, \mathrm{Nb}$, Ta, and lower concentrations of $\mathrm{CaO}, \mathrm{MgO}, \mathrm{FeO}, \mathrm{TiO}_{2} \mathrm{Ba}, \mathrm{Sr}$ than the low Ca-granite of Turekian and Wedepohl (1961). Except for Bir Um Hibal pluton, the rare metal granites have comparable values of $\mathrm{Rb}, \mathrm{Ba}, \mathrm{Sr}$ (being $>200 \mathrm{ppm},<200 \mathrm{ppm}$ and $<80$ ppm respectively, Table-1) with those of the specialized granites of Tischendorf(1977). The investigated granites have also very low $\mathrm{K} / \mathrm{Rb}, \mathrm{Ba} / \mathrm{Rb}$, and $\mathrm{Al} / \mathrm{Ga}$ ratios and very high $\mathrm{Rb} / \mathrm{Sr}$ ratio, equivalent to those recorded by Matheis et al. (1982) and Ramsay (1986) for mineralized granites from Nigeria and Saudi Arabia respectively.

On the $\mathrm{Al} /(\mathrm{Na}+\mathrm{K}+\mathrm{Ca})-\mathrm{Al} /(\mathrm{Na}+\mathrm{K})$ diagram (Fig. 11), the investigated granites can be discriminated into two main groups; 
COMPARATIVE STUDY ON THE GEOLOGICAL AND GEOCHEMICAL

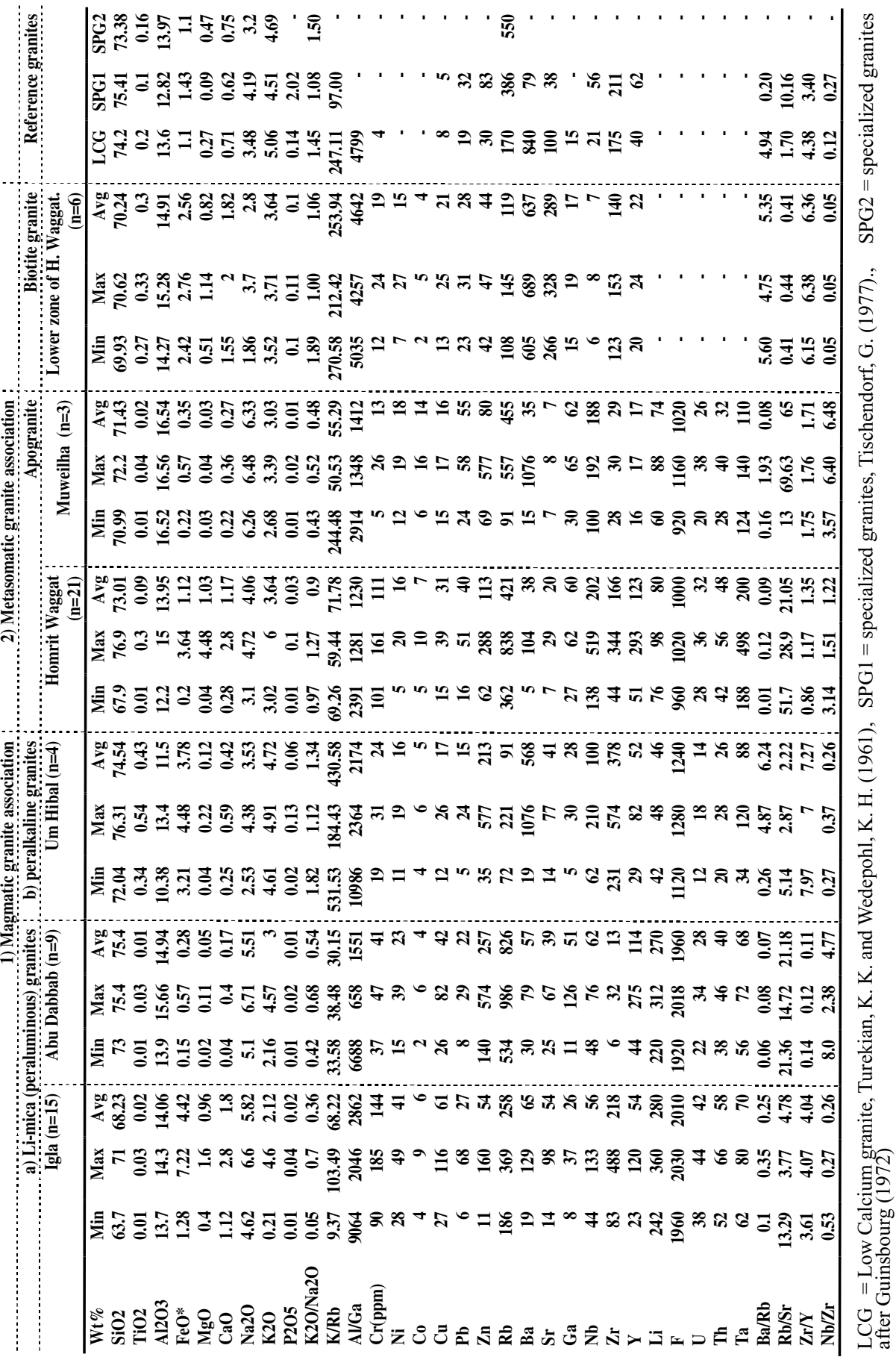




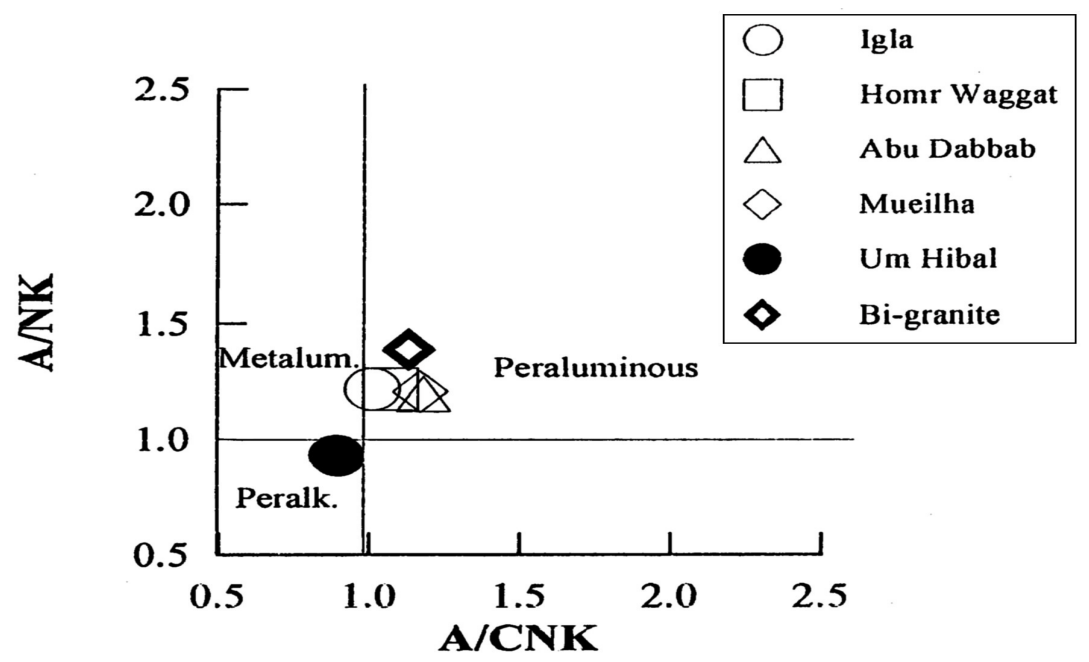

Fig. 11: $\mathrm{Al}_{2} \mathrm{O}_{3} /\left(\mathrm{Na}_{2} \mathrm{O}+\mathrm{K}_{2} \mathrm{O}\right)$ vs $\mathrm{Al}_{2} \mathrm{O}_{3} /\left(\mathrm{CaO}+\mathrm{Na}_{2} \mathrm{O}+\mathrm{K}_{2} \mathrm{O}\right)$ molar diagram for the studied rare-metal granites (After Maniar and Piccoli ,1989)

peraluminous-metaluminous group of $\mathrm{A} /$ CNK ratios more than 1 (Igla, Abu Dabbab, Homrit Waggat and Muweilha granites and peralkaline group of $\mathrm{A} / \mathrm{CNK}$ ratio less than 1 (Bir Um Hibal granite). The peraluminous nature of the metasomatized varieties could be attributed to the immobile nature of $\mathrm{Al}$ during metasomatic processes whereas the peraluminous nature of the primary varieties could be ascribed to evolved fractionation of metaluminous magma. Moreover, the peraluminous varieties have many chemical features of the I-type granites mainly low $\mathrm{K} / \mathrm{Na}(0.4-0.9)$, $\mathrm{Ba} / \mathrm{Sr}(<2) \mathrm{Ba}(15-65 \mathrm{ppm}), \mathrm{Zr}(<250 \mathrm{ppm})$, while the peralkaline variety has features of the A-type granites; high $\mathrm{K} / \mathrm{Na}(>1), \mathrm{Ba} / \mathrm{Sr}$ $(>10), \mathrm{Ba}(>500 \mathrm{ppm}), \mathrm{Zr}$ (>300 ppm).

Based on $\mathrm{K}_{2} \mathrm{O} / \mathrm{Na}_{2} \mathrm{O}$ ratios, the studied peraluminous-metaluminous rare metal granites could be subdivided into two main subtypes; sodic and potassic. The sodic varieties have low values of $\mathrm{K}_{2} \mathrm{O} / \mathrm{Na}_{2} \mathrm{O}$ ratio $(<0.7)$ and are represented by two types of the magmatic varieties; the albite granites of Igla and Li-albite granite of Abu Dabbab plutons in addition to the sodic metasomatic granites of $\mathrm{Mu}$ - weilha pluton. In all cases, the sodic varieties are dominated by high $\mathrm{Ta} / \mathrm{Nb}$ ratios (tantalite mineralization) and Li-rich micas (Abdalla et al, 1998 and Mohamed et al., 1999). The potassic varieties have $\mathrm{K}_{2} \mathrm{O} / \mathrm{Na}_{2} \mathrm{O}$ ratios $>0.7$ and are represented by Homrit Waggat pluton which exhibits pervasive potassic metasomatic alteration. They are characterized by high $\mathrm{Nb} / \mathrm{Ta}$ ratios (culombite mineralization) and annite-siderophyllite micas (Abdalla et al., 1998 and Mohamed et al., 1999).

\section{RADIOMETRIC CHARACTERISTICS}

Radiometrically, Igla pluton has the highest average contents of $U$ \& Th (42 ppm \& 58 ppm respectively). Um Hibal pluton has the lowest average contents of $U$ \& Th (14 ppm \& 26 ppm respectively).

\section{DISCUSSION AND CONCLUSION}

The main geological, petrographical, geochemical and radiometric characteristics of the studied five rare metal granitic plutons are summarized in Table (2).

It is revealed that the rare metal granites 
Table. 2: Summary for the geological and geochemical characteristics of the studied raremetal granites, south Eastern Desert, Egypt

\begin{tabular}{|c|c|c|c|c|c|}
\hline \multirow[t]{2}{*}{ Criterion } & \multirow[b]{2}{*}{ Igla pluton } & \multicolumn{2}{|c|}{ Magmatic associations } & \multicolumn{2}{|c|}{ Metasomatic associations } \\
\hline & & $\begin{array}{r}\text { Abu Dabbab } \\
\text { pluton }\end{array}$ & $\begin{array}{r}\text { Bir Um Hibal } \\
\text { pluton }\end{array}$ & $\begin{array}{c}\text { Homrit } \\
\text { Wagget } \\
\text { pluton }\end{array}$ & $\begin{array}{r}\text { Muweilha } \\
\text { pluton }\end{array}$ \\
\hline $\begin{array}{l}\text { Geologic } \\
\text { occurrence }\end{array}$ & \multicolumn{2}{|c|}{$\begin{array}{l}\text { Occur as small stocks of } \\
\text { circular, ovoid or apophyses } \\
\text { outcrops and leucocratic } \\
\text { nature }\end{array}$} & $\begin{array}{l}\text { Plugs and } \\
\text { dyke-like } \\
\text { intrusions with } \\
\text { pinkish colour }\end{array}$ & \multicolumn{2}{|c|}{$\begin{array}{l}\text { Small areas and exhibit } \\
\text { obvious pervasive post } \\
\text { magmatic alterations }\end{array}$} \\
\hline $\begin{array}{l}\text { Petrographic } \\
\text { features }\end{array}$ & \multicolumn{2}{|c|}{$\begin{array}{l}\text { Consist essentrially of } \\
\text { quartz, albite, K-feldspars } \\
\text { and Li-mica. Topaz, } \\
\text { columbite-tantalite, beryl, } \\
\text { cassiterite and fluorite are } \\
\text { the main accessories. } \\
\text { Texturally, they are } \\
\text { characterized by fine- } \\
\text { grained to porphyritic } \\
\text { texture with quartz and K- } \\
\text { feldspar phenocrysts } \\
\text { embedded in albite-rich } \\
\text { groundmass. }\end{array}$} & $\begin{array}{l}\text { Composed } \\
\text { mainly of } \\
\text { quartz, } \\
\text { perthite, albite } \\
\text { and alkali } \\
\text { amphiboles } \\
\text { and pyroxenes } \\
\text { (riebeckite and } \\
\text { arvfedsonite). } \\
\text {-Hypersolvus, } \\
\text { medium- } \\
\text { grained with } \\
\text { equigranular } \\
\text { to porphyritic } \\
\text { texture. }\end{array}$ & \multicolumn{2}{|c|}{$\begin{array}{l}\text { Characterized by vertical } \\
\text { petrographical zoning with a } \\
\text { lower unaltered zone } \\
\text { followed upward by } \\
\text { microclinization, albitization } \\
\text { and greisenization zones. } \\
\text { The lower unaltered zone is } \\
\text { either represented by biotite } \\
\text { granite (Humrit Waggat) or } \\
\text { alkali feldspar granite } \\
\text { (Muweilha). Microclinzation } \\
\text { and albitization zones are } \\
\text { well developed at Humrit } \\
\text { Waggat, whereas albitization } \\
\text { and greisenization zones are } \\
\text { principally developed at } \\
\text { Mueilha. }\end{array}$} \\
\hline $\begin{array}{l}\text { Geochemical } \\
\text { characteristics }\end{array}$ & \multicolumn{2}{|c|}{$\begin{array}{l}\text { Peraluminous ( } \mathrm{Li}-\mathrm{mica} \\
\text { rich). -Enriched in Nb, Rb, } \\
\text { Ta, Li, F, Y and } \mathrm{Zr} \text { elements. }\end{array}$} & $\begin{array}{l}\text { (riebeckite } \\
\text { and/or } \\
\text { arfvedsonite } \\
\text { rich). } \\
\text {-Enriched in } \\
\mathrm{K}_{2} \mathrm{O}, \mathrm{Zr}, \mathrm{Nb}, \mathrm{F} \\
\text { and Ta } \\
\text { elements }\end{array}$ & \multicolumn{2}{|c|}{$\begin{array}{l}\text {-Enriched in } \mathrm{Na}_{2} \mathrm{O}, \mathrm{Nb}, \mathrm{Ta}, \\
\text { and } \mathrm{Rb} \text { elements. } \\
\text {-Have distinct higher } \\
\text { contents of } \mathrm{Nb} / \mathrm{Zr}, \mathrm{Rb} / \mathrm{Sr}, \\
\mathrm{K} / \mathrm{Rb} \text { and distinct lower } \\
\text { contents of } \mathrm{Ba}, \mathrm{Sr}, \mathrm{Ba} / \mathrm{Rb} \\
\text { than the magmatic varieties. }\end{array}$} \\
\hline Alterations & \multicolumn{3}{|c|}{ Less altered granite } & $\begin{array}{r}\text { Dominantly } \\
\text { with potassic } \\
\text { alteration }\end{array}$ & $\begin{array}{r}\text { Dominantly } \\
\text { with sodic } \\
\text { alteration }\end{array}$ \\
\hline $\begin{array}{l}\text { Radiometric } \\
\text { characteristics }\end{array}$ & $\begin{array}{l}\text { Has highest } \\
\text { average } U \text { \& } \\
\text { Th contents } \\
(42 \& 58 \\
\text { respectively }\end{array}$ & $\begin{array}{l}\text { Averages of } \\
U \& \text { Th } \\
\text { contents are } \\
(28 \& 40 \\
\text { respectively }\end{array}$ & $\begin{array}{l}\text { Averages of } U \\
\& \text { Th contents } \\
\text { are }(14 \& 26 \\
\text { respectively }\end{array}$ & $\begin{array}{l}\text { Averages of } \\
U \& \text { Th } \\
\text { contents are } \\
(32 \& 48 \\
\text { respectively }\end{array}$ & $\begin{array}{l}\text { Averages of } \\
U \& \text { } T h \\
\text { contents are } \\
(26 \& 32 \\
\text { respectively }\end{array}$ \\
\hline
\end{tabular}

under investigation can be subdivided into two main groups: magmatic associations (Igla, Abu Dabbab and Bir Um Hibal plutons) and metasomatic associations (Homrit Wagget pluton and Muweilha pluton). Igla and Abu Dabbab granites occur as small stocks, while Bir Um Hibal pluton occurs as plugs and dyke-like intrusions. Homrit Waggat and Muweilha plutons are found as small areas. Petrographically, the magmatic varieties are characterized by prevailing magmatic textures represented by sharp grain boundaries, absence of corroded outlines, and the fresh appearance of mineral crystals. On the other hand the mineral constituents of the metasomatic varieties are characterized by corroded outlines and altered appearance.

Geochemically, The magmatic granite association is further subdivided into two subgroups; i) peraluminous granite (Li-mica rich) including Igla and Abu Dabbab plutons and ii) peralkaline granite (riebeckite and/or arfvedsonite rich) including Um Hibal pluton. The studied peraluminous granites are generally enriched in $\mathrm{Nb}, \mathrm{Rb}$, Ta, Li, F, Y and $\mathrm{Zr}$ elements. The peralkaline granites are enriched in $\mathrm{K}_{2} \mathrm{O}, \mathrm{Zr}, \mathrm{Nb}, \mathrm{F}$ and $\mathrm{Ta}$. On the other hand, 
the metasomatic granite association (apogranite) is represented by Homrit Waggat and Muweilha plutons. They are characterized by high contents of $\mathrm{Na}_{2} \mathrm{O}, \mathrm{Nb}, \mathrm{Ta}$, and $\mathrm{Rb}$.

The metasomatic varieties have distinct higher contents of $\mathrm{Nb}, \mathrm{Rb} / \mathrm{Sr}, \mathrm{K} / \mathrm{Rb}$ and distinct lower contents of $\mathrm{Ba}, \mathrm{Sr}, \mathrm{Ba} / \mathrm{Rb}$ than the magmatic varieties. These reveal two trends of differentiations; potassium-rich trend (normal or least differentiated trend) which comprise potassium feldspar-rich leucogranites (e.g. Homrit Waggat). The other is sodiumrich one (highly fractionated trend) which comprise albite-rich leucogranites (e.g. Igla and Abu Dabbab). Chemically the two group varieties show obvious trends on the variation diagrams. The metasomatic varieties are the reflection of the two trends mentioned above, where the Na-rich residual melt cause sodic alteration and the K-rich residual melt cause potassium metasomatism.

Radiometrically, Igla pluton has the highest average contents of $U$ \& Th (42 ppm \& 58 ppm respectively). Um Hibal pluton has the lowest average contents of U \& Th (14 ppm \& 26 ppm respectively).

\section{Acknowledgements}

The authors wish to express their deep gratitude to Prof. Dr. H. A., Abdalla, Research Sector, Nuclear Materials Authority for kind help and reviewing the manuscript.

\section{REFERENCES}

Abdalla, H.M.; Matsueda, H., Ishihara, S., and Miura, H., 1994. Mineral chemistry of albiteenriched granitoids at Um Ara area, Southeastern Desert, Egypt. Inst. Geol. Rev., 36, 10671077.

Abdalla, H.M., and El Afandy, A.H., 2003. Contrastng Mineralogical and Geochemical characterstics of two A-Type pegmatite fields, Eastern Desert, Egypt. Egyptian Mineralogist, $15,1-42$.

Abdalla, H.M., and Mohamed, F.H.,1999. Mineralogical and geochemical investigation of emerald and beryl mineralization, Pan-African belt of Egypt: genetic and exploration aspects. J. Afri. Earth Sci., 28, No. 3, 581-598.

Abdalla, H.M.; Helba, H.A., and Mohamed, F.H., 1998. Chemistry of columbite-tantalite minerals in rare metal granitoids. Eastern Desert, Egypt. Mineral. Mag., 62(6), 821-836.

Collins, W.J.; Beams, S.D.; White, A.,J., and Chappell, B.W., 1982. Nature and origin of A-type granites with particular reference to southeastern Australia. Contrib. mineral. Petrol., 80, $189-200$.

El Gaby, S.; List, F.K., and Tehrani, R., 1990. The basement complex of the Eastern Desert and Sinai. In: The geology of Egypt (Said, R., Ed.). Balkama-Rotterdam-Brookfield, 175-184.

Garson, M.S., and Krs, M., 1976. Geophysical and geological evidence of the relationship of Red Sea transverse tectonics to ancient fractures. Bull. Geol. Soc. Am., 87, 169 - 181.

Greenberg, J.K.,1981. Characteristics and origin of Egyptian younger granites. Summary. Bull. Geol. Soc. Amer., Part 1, 92, 224 - 232.

Guinsbourg, A.I., 1972. Rare metal granites and problems of magmatic differentiation, Nedra Publishing Hous, Moscow.

Hashad, A.H., and El Reedy, M.W., 1981. Geochronological and strontium isotope study of psammitic gneiss of Wadi Nugrus, Eastern Desert, Egypt. J. Geol., 25, 1-2.

Hassan, M.A., and Hashad, A., 1990. Precambrian of Egypt. In: The geology of Egypt(Said, R., Ed.). balkema-Rotterdam and Brookfield Pub.

Helba, H.; Trumbul R.B.; Morteani, G.; Khalil, S.O., and Arslan, A., 1997. Geochemical and petrographic studies of Ta mineralization in the Nuweibi albite granite complex, Eastern Desert, Egypt. Mineralium Deposita, 32, 164179.

Kovalenko, V.I.,1978. The genesis of rare metal granitoids and related ore deposits. In: Mineralization associated with acid magmatism 
(Stempork, M.; Burnal, L., \& Tischendorf, G., Eds.). Geol. Surv. Prague, 3, $235-247$.

Loiselle, M.C., and Wones, D.R., 1979. Characteristics and origin of anorogenic granites. Geol. Soc. Am., 11, 486p.

Maniar, P.D. , and Piccoli, P.M.,1989. Tectonic discriminations of granitoids. Geol. Soc. Amer. Bull., 101, 635-643.

Matheis, G.; Emofurieta, W.O., and Ohiwerei, S. F., 1982. Trace element distribution in tinbearing pegmatites of southwestern Nigeria. In: Metallization associated with acid magmatism (Evans, A. M., Ed.). Wiley, London, 205-220.

Mohamed, F.H., 1989. Geochemical prospecting in Nugrus area, Southern Eastern Desert, Egypt. Ph. D. Thesis, Alex. Univ., 201p.

Mohamed, F.H.; Abdalla, H.M., and Helba, H., 1999. Chemistry of micas in rare metal granitoids and associated rocks. Eastern Desert, Egypt. Inter. Geol. Review, 41, 932-948.

Pitcher, W.S.,1983.Granite type and tectonic environment. In: Mountain building processes(Hsu, K.,ed.). Academic press, London, $19-40$.

Pollard, P.J., 1989. Geochemistry of granites associated with tantalum and niobium mineralization. In: Lanthanides, Tantalum and Niobium (Moeller, P.; Cerny, P., \& Saupe, F., Eds). Springer-Verlag, 380, 145-168.
Pollard, P.J., 1995. Geology of rare metal deposits: An introduction and overview. Economic Geology, 90(3), 489-494.

Ramsy, C.R., 1986. Geologic map of the Rabigh quadrangle, sheet 22D, Kingdom of Saudi Arabia, Saudi arabian Deputy ministry for mineral resources geoscience map GM 84C, Scale 1:250 000, with text, 49p.

Sabet, A.H.; Tsogove, V.B.; Bessonenkov, V.V.; Babourin, L.M., and Pokryshkin, V.I., 1976. Some geological and tectonic peculiarities of the Central Eastern desert of Egypt. Ann. Geol. Surv. Egypt, 6, 33-52.

Schwartz, M.O., 1992. Geochemical criteria for distinguishing magmatic and metasomatic albite-enrichment in granitoids-examples from the Ta-Li granite Yichun (China) and Sn-W deposit Tikus (Indonesia). Mineralium deposita, 27, 101-108.

Tischendorf, G., 1977. Geochemical and petrographic characteristics of silicic magmatic rocks associated with rare metal mineralization. In: Metallization associated with acid magmatism 2(Stemprok, M.; Burnol, L.,\& Tischendorf, G., Eds). Usterdni Ustav Geologicky, Prague, 41-98.

Turekian, K.K., and Wedepohl, K.H., 1961. Distribution of the elements in some major units of earth's crust. Geol. Soc. Amer. Bull., 72, 175-192.

$$
\begin{aligned}
& \text { دراسة مقارنة علي الخصائص الجيولوجية و الجيوكيميائية لبعض الجرانيتات ذات الفلزات النادرة، }
\end{aligned}
$$

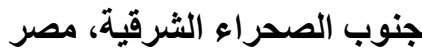

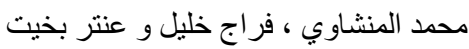

$$
\begin{aligned}
& \text { تتميز الجرانيتات الحديثة في مصر بوجود أكثر من ع ا مكثف من الجرانيتات ذات الفلزات النادرة. } \\
& \text { تهدف الدراسة الحالية الي مقارنة الخصائص الجيولوجية و الجيوكيميائية لخمسة متذاخلات من هذه الجرانية انيتات } \\
& \text { ذات الفلزات النادرة وهي العجلة، أبودباب، حمرة وقات، المويلحة و ولئر أم حبال. }
\end{aligned}
$$

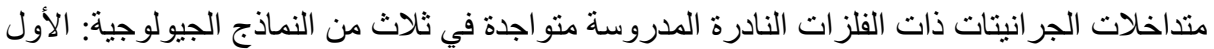

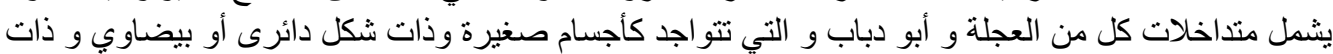

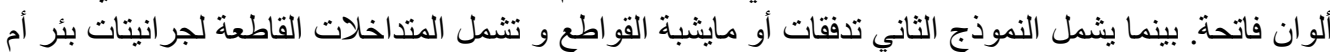

$$
\begin{aligned}
& \text { حبال. بينما يمثل النموذج الثالث بمتداخلي حمرة وقات و المويلحة. و تغطي بمساحات صغيرة وتظهر تحلل مابعد }
\end{aligned}
$$




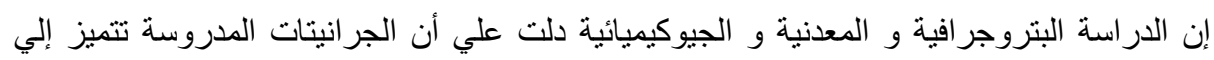

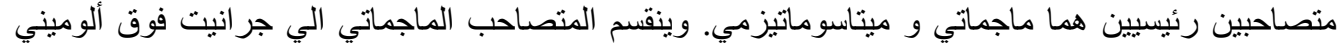

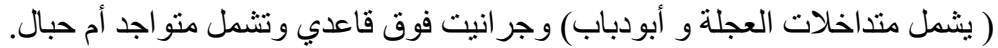

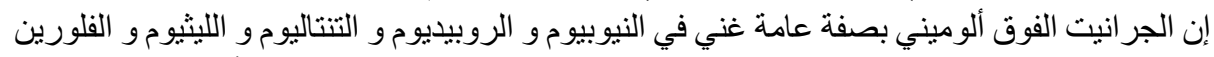

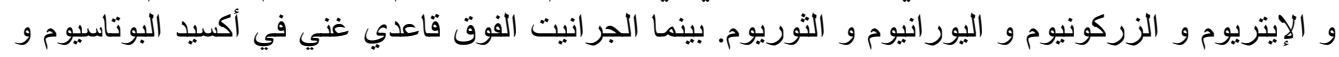
الزركونيوم و النيوبيوم و الفلورين و واليونيور اليوم انيوم و الثنوريوم و التنتاليوم.

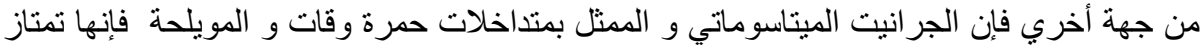

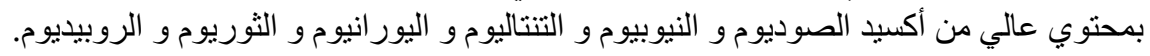

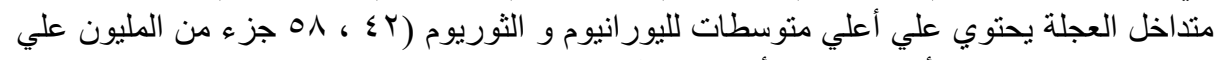

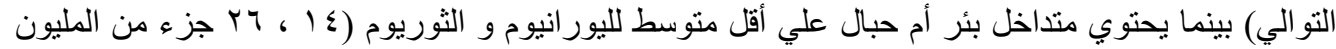

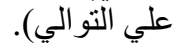

